\title{
Airway and cough responsiveness and exhaled nitric oxide in non-smoking patients with stable chronic heart failure
}

\author{
T P Chua, U G Lalloo, M Y Worsdell, S Kharitonov, K F Chung, A J S Coats
}

\begin{abstract}
Objective-To investigate the airway and cough responsiveness in non-smoking patients with stable chronic heart failure. Cough and wheeze, features associated with hyper-responsive airways, are not uncommon especially in decompensated chronic heart failure. Bronchial hyperresponsiveness has previously been demonstrated in chronic heart failure but this may have been confounded by smoking and acute decompensation.
\end{abstract}

Design-Case-control study.

Setting-Tertiary specialist hospital.

Patients and interventions-Airway responsiveness to methacholine (a direct stimulant of smooth muscle in the airways), sodium metabisulphite (a putative stimulant of airway sensory nerves), and exercise was examined in 10 non-smoking patients with stable chronic heart failure (age 56.5 (3.2) (SEM) years; 7 men; radionuclide left ventricular ejection fraction $20.8(2.9) \%$; radiographic cardiothoracic ratio $0.56(0.02))$. Exhaled nitric oxide, a product of the action of proinflammatory cytokines, was also measured to assess the contribution of local inflammation to airway responsiveness. The cough responses to low-concentration chloride solutions and to capsaicin were studied. Because all patients were receiving angiotensin-converting enzyme inhibitors, which may influence airway responsiveness and cough, 8 asymptomatic non-smoking controls taking angiotensin-converting enzyme inhibitors for essential hypertension were also studied (age 54.3 (2.8) years; 6 men; radiographic cardiothoracic ratio $0.46(0 \cdot 01))$. Results-The mean provocative concentration that induced a $20 \%$ decrease in forced expiratory volume in 1 second $\left(\mathrm{FEV}_{1}\right)$ was $67.6 v 79.8 \mathrm{mg} / \mathrm{ml}(P=0.71)$ for methacholine and $276.7 v 290.4 \mathrm{mg} / \mathrm{ml}$ $(P=0.79)$ for sodium metabisulphite in chronic heart failure patients and controls respectively. The change in $\mathrm{FEV}_{1}$ after maximal cardiopulmonary exercise testing was $+1.44 \%$ in patients and $+2.53 \%$ in controls $(P=0.47)$, indicating that there was no exercise-induced bronchospasm in either group (peak oxygen consumption was $16.9(1.3)$ v $26.5(2 \cdot 3)$ $\mathrm{m} 1 / \mathrm{kg} / \mathrm{min} \quad$ respectively, $\quad P<0.01$ ). Exhaled nitric oxide concentration was not increased in chronic heart failure $(12.3(1 \cdot 7) v 16 \cdot 2(3 \cdot 3) \mathrm{ppb}, P=0.32)$. The median cough counts after nebulised 0 $\mathrm{mM}$ and $37.5 \mathrm{mM}$ chloride solutions were $2.5 v 1.0(P=0.6)$ and $5.5 v 5.5(P=0.5)$ respectively and the capsaicin concentration causing two or more coughs was $13.5 v$ $6.5 \mu \mathrm{M}(\mathbf{P}=0.5)$.

Conclusion-Airway hyper-responsiveness is not a predominant feature in nonsmoking patients with stable chronic heart failure treated with, and tolerant to, angiotensin-converting enzyme inhibitors. It is unlikely to contribute to the exertional dyspnoea seen in these patients.

(Heart 1996:76:144-149)

Keywords: airway responsiveness; cough response; exhaled nitric oxide; chronic heart failure

Exertional dyspnoea is a limiting symptom in chronic heart failure. Cough and wheeze, features associated with hyper-responsive airways, are not uncommon especially in decompensated chronic heart failure. Classically, non-specific bronchial hyperresponsiveness is seen in bronchial asthma ${ }^{1}$ and is assessed using aerosols of histamine and acetylcholine or its analogue, methacholine, with monitoring of the bronchochoconstrictor response in terms of the reduction in forced expiratory volume. Several studies have described bronchial hyper-responsiveness in chronic heart failure ${ }^{2-5}$ but this is not a unanimous finding. ${ }^{67}$ The number of patients in these studies are small and the findings are often confounded by acute decompensation of chronic heart failure, current smoking, or stopping treatment (including diuretics) before assessment. Pison et al found that bronchial hyper-responsiveness in patients with decompensated chronic heart failure did not improve 5-15 days after increased diuretic treatment, confirming that a recent history of acute pulmonary oedema may affect bronchial responsiveness. ${ }^{3}$ Cabanes et al showed that inhalation of the vasoconstrictor methoxamine, an alpha-receptor agonist, lessened the methacholine-induced bronchial hyperresponsiveness and suggested that bronchial hyper-responsiveness was in part due to the vasodilatory effect of methacholine causing further oedema and narrowing of the airways even without an increase in smooth muscle tone. ${ }^{2}$ Some investigators have postulated that, in addition to airway oedema, a neural reflex mediates bronchial hyperresponsiveness. ${ }^{48}$ 
This may be secondary to the stimulation of pulmonary stretch $(J)$ receptors by raised pulmonary venous pressure, although a significant correlation between pulmonary haemodynamics and bronchial hyper-responsiveness could not be demonstrated. Local airway inflammation has also been suggested as a cause of bronchial hyper-responsiveness but the presence of inflammatory cells and mediators has yet to be explored. ${ }^{3}$

To investigate the role of bronchial hyperresponsiveness in the generation of dyspnoea in chronic heart failure and to help in the understanding of the pathophysiology of this condition, we investigated several aspects of airway responsiveness in patients with chronic heart failure who were stable and nonsmoking. This avoids the possible confounding factors discussed above. Specifically, we examined whether the the airways were hyperresponsive to: (a) methacholine, a direct airway smooth muscle stimulant; (b) sodium metabisulphite, a putative stimulant of airway sensory nerves; and $(c)$ exercise. In addition, the cough responses to low-concentration chloride solutions and capsaicin were studied. We also investigated whether exhaled nitric oxide concentrations were increased in these patients as they are in patients with inflammatory airway disease, such as asthma, due to the action of proinflammatory cytokines. ${ }^{910}$

\section{Patients and methods}

Ten patients (age range 40-68 years, mean $56.5(3 \cdot 2)$ (SEM) years; seven men and three women) with stable symptomatic chronic heart failure and no history of acute decompensation within six months of the study were recruited. Patients were non-smokers or had stopped smoking for at least five years before the study. Patients with a history of asthma, chronic obstructive airways disease, or other airway disease were excluded. All had a radionuclide left ventricular ejection fraction of less than $35 \%$ (range $9-33 \%$, mean 20.8 $(2.9) \%)$ and were receiving stable treatment with both diuretic (mean daily dose of frusemide $80 \mathrm{mg}$, range $40-200 \mathrm{mg}$ ) and angiotensin-converting enzyme inhibitor medication. None was limited by angina although three patients were taking calcium antagonists and four nitrates. All patients had cardiac catheterisation before the study (eight with right and left heart studies, two with left heart only). Standard lung function tests and chest radiographs (mean radiographic cardiothoracic ratio $0.56(0.02)$ ) were also performed in these patients. Because all patients were receiving angiotensin-converting enzyme inhibitors, which may influence airway responsiveness and cough, eight asymptomatic non-smoking controls taking angiotensin-converting enzyme inhibitors for essential hypertension were also studied (age range 42-65 years, mean $54.3(2 \cdot 8)$ years; six men and two women; radiographic cardiothoracic ratio 0.46 $(0.01))$. None of the subjects was troubled by cough during treatment with angiotensin-converting enzyme inhibitors. Table 1 shows the clinical characteristics of the patients with chronic heart failure. This study was approved by the local ethics committee and all subjects gave written informed consent.

BRONCHIAL PROVOCATION TESTS

Airway responsiveness was assessed after the inhalation of two pharmacological agents, methacholine and sodium metabisulphite, and after maximal cardiopulmonary exercise testing. Increasing doubling concentrations of methacholine and sodium metabisulphite, ranging from $1 \mathrm{mg} / \mathrm{ml}$ to $64 \mathrm{mg} / \mathrm{ml}$ and from 5 $\mathrm{mg} / \mathrm{ml}$ to $160 \mathrm{mg} / \mathrm{ml}$ respectively, with preceding saline solution as baseline were used. Each provocation test was done separately on two different occasions using a nebuliser attached to a dosimeter (model MB3, MEFAR Electromedical, Brescia, Italy; output $0.14 \mathrm{ml}$ per solution). Forced expiratory volume in 1 second $\left(\mathrm{FEV}_{1}\right)$ was measured 2 minutes after each test with a spirometer (Vitalograph, USA). Doubling concentrations were used every 5 minutes until a $\geqslant 20 \%$ fall in $\mathrm{FEV}_{1}$ from the baseline was noted, or until the maximal concentration for each agent was reached if the fall in $\mathrm{FEV}_{1}$ remained $<20 \%$ from baseline. The provocation concentration causing a $20 \%$ fall in $\mathrm{FEV}_{1}$ (PC20) was then calculated by linear interpolation. If the fall in $\mathrm{FEV}_{1}$ remained $<20 \%$ at a methacholine concentration of $64 \mathrm{mg} / \mathrm{ml}$ and a sodium metabisulphite concentration of $160 \mathrm{mg} / \mathrm{ml}$, the PC20 was arbitrarily taken as the next doubling concentration of $128 \mathrm{mg} / \mathrm{ml}$ and $320 \mathrm{mg} / \mathrm{ml} \mathrm{respec-}$ tively, for the purposes of statistical analysis. Although this may underestimate the PC20 of some patients, such concentrations are high (the PC20 of asthmatic patients is $<8 \mathrm{mg} / \mathrm{ml}$ and $<40 \mathrm{mg} / \mathrm{ml}$ for methacholine and sodium metabisulphite respectively in our laboratory) and can therefore be regarded as values consistent with a negative provocation test.

CARDIOPULMONARY EXERCISE TESTING

$\mathrm{FEV}_{1}$ was assessed with a spirometer (Vitalograph, USA) before and after maximal treadmill exercise testing on a separate day to examine whether the the airways were hyperresponsive to exercise. Respiratory gas exchange was also analysed during exercise testing to determine peak oxygen consumption as an objective measure of functional capacity. This was done using a respiratory mass spectrometer (Amis 2000, Innovision, Odense, Denmark) by means of the inert gas dilution technique. ${ }^{11}$ All subjects exercised to exhaustion using the Bruce protocol, ${ }^{12}$ with the addition of "stage 0 " at $1.0 \mathrm{mph}$ and a $5 \%$ gradient.

\section{COUGH RESPONSE}

The cough response was assessed using lowconcentration chloride solutions and capsaicin. Four iso-osmolar solutions with decreasing chloride concentrations (150, 75, $37 \cdot 5$, and $0 \mathrm{mM}$ ) were used. Inhalations of the solutions were taken for a minute each from an ultrasonic nebuliser (Ultra-Neb 2000, DeVilbiss, Somerset, Pennsylvania, USA) 
Table 1 Clinical characteristics of patients with chronic heart failure

\begin{tabular}{|c|c|c|c|c|c|c|c|c|c|c|}
\hline Patient & Age (yr) & Sex & Cause & $\begin{array}{l}\text { NYHA } \\
\text { class }\end{array}$ & $\begin{array}{l}\text { Smoking } \\
\text { history } \\
\text { (pack-years) * }\end{array}$ & $\begin{array}{l}\text { LV ejection } \\
\text { fraction } \\
(\%)\end{array}$ & $\begin{array}{l}P C W P \\
(m m H g)\end{array}$ & $\begin{array}{l}\text { LVEDP } \\
(m m \mathrm{Hg})\end{array}$ & $C X R C T R$ & $\begin{array}{l}\text { Maximum } O_{2} \\
\text { consumption } \\
\text { (ml/kg/min) }\end{array}$ \\
\hline 1 & 64 & $\mathrm{~F}$ & DCM & III & $1 \cdot 2$ & 13 & 5 & 11 & 0.50 & 13.9 \\
\hline 2 & 52 & $\mathrm{~F}$ & $\mathrm{DCM}$ & III & 6 & 27 & 12 & 16 & 0.56 & $13 \cdot 6$ \\
\hline 3 & 66 & M & DCM & II & 88 & 33 & Not done & 19 & 0.51 & $22 \cdot 4$ \\
\hline 4 & 40 & M & DCM & IV & Nil & 8 & 26 & 40 & $0 \cdot 66$ & $17 \cdot 8$ \\
\hline 5 & 46 & M & IHD & II & 26 & 28 & 14 & 21 & 0.50 & $19 \cdot 1$ \\
\hline 6 & 47 & M & IHD & II & Nil & 18 & Not done & 26 & 0.57 & $24 \cdot 8$ \\
\hline 7 & 66 & M & IHD & III & Nil & 9 & 24 & 22 & 0.58 & 13.9 \\
\hline 8 & 68 & M & IHD & III & Nil & 15 & 17 & 24 & 0.64 & $17 \cdot 3$ \\
\hline 9 & 63 & $\mathrm{~F}$ & $\mathrm{DCM}$ & III & 11 & 29 & 16 & 18 & 0.55 & $12 \cdot 0$ \\
\hline 10 & 53 & $M$ & IHD & III & 1.5 & 28 & 25 & 27 & $0 \cdot 50$ & $13 \cdot 7$ \\
\hline
\end{tabular}

DCM, idiopathic dilated cardiomyopathy; IHD, ischaemic heart disease; NYHA, New York Heart Association functional class; LV, left ventricle; PCWP, pulmonary capillary wedge pressure; LVEDP, left ventricular end diastolic pressure; CXR CTR, radiographic cardiothoracic ratio.

${ }^{\star}$ All patients with a smoking history had stopped smoking for at least 5 years.

Pack year $=($ number of cigarettes smoked per day $\times$ number of years smoking $) / 20$.

through the mouth with the subject wearing a noseclip. The number of coughs induced during and 1 minute after nebulisation for each solution was counted by observation. For the capsaicin test, doubling concentrations of capsaicin ranging from 0.975 to $500 \mu \mathrm{M}$ were used. Single breath inhalations of $0.02 \mathrm{ml}$ solution of each concentration were administered through the mouth from a breathactivated dosimeter (PK Morgan, Gillingham, Kent). The concentration of capsaicin which produced two or more coughs was taken as the threshold concentration. For the purpose of statistical analysis, subjects who had more than two coughs at $500 \mu \mathrm{M}$ capsaicin were assumed to have a threshold of the next doubling concentration $(1000 \mu \mathrm{M})$.

\section{NITRIC OXIDE MEASUREMENT}

Exhaled nitric oxide concentration was measured with a modified chemiluminescence analyser (Model LR2000, Logan Research, Rochester, Kent) designed for on-line recording of exhaled nitric oxide and sensitive to concentrations of 2 to 4000 parts per billion (ppb) by volume. ${ }^{9}$ Measurements were made by slow exhalation from the mouth for 30-45 seconds from total lung capacity via a widebore Teflon tube. Subjects wore a nose-clip and the rate of expiration was kept constant by a visual display of expiratory flow measured by flow sensors in the analyser. The average of

Table 2 Summary of results of peak oxygen consumption; radiographic cardiothoracic ratio (CTR); pulmonary function; airway responsiveness to methacholine (MCh), sodium metabisulphite (MBS), and exercise; exhaled nitric oxide concentration; and the cough response to capsaicin and low-concentration chloride solutions in patients with chronic hear failure $(\mathrm{CHF})$ and controls

\begin{tabular}{|c|c|c|c|}
\hline Variable & CHF Patients & Controls & $\mathrm{P}$ value \\
\hline $\begin{array}{l}\text { Peak } \mathrm{O}_{2} \text { consumption }(\mathrm{ml} / \mathrm{kg} / \mathrm{min}) \\
\text { Radiographic CTR } \\
\text { FEV }_{1}(\% \text { predicted }) \\
\text { FVC }(\% \text { predicted })\end{array}$ & $\begin{array}{c}16 \cdot 9(1 \cdot 3) \\
0.56(0 \cdot 02) \\
97 \cdot 2(4 \cdot 5) \\
102 \cdot 2(5 \cdot 1)\end{array}$ & $\begin{array}{c}26 \cdot 5(2 \cdot 3) \\
0 \cdot 46(0 \cdot 01) \\
110 \cdot 0(2 \cdot 5) \\
112 \cdot 6(2 \cdot 9)\end{array}$ & $\begin{array}{l}<0.01 \\
<0 \cdot 001 \\
0.03 \\
\text { NS }\end{array}$ \\
\hline $\begin{array}{l}\mathrm{PC} 20 \mathrm{MCh}(\mathrm{mg} / \mathrm{ml}) \\
\text { PC20 MBS }(\mathrm{mg} / \mathrm{ml}) \\
\% \text { Change in } \mathrm{FEV}, \text { with exercise }\end{array}$ & $\begin{array}{l}67 \cdot 6(1 \cdot 3) \\
276 \cdot 7(1 \cdot 2) \\
1 \cdot 44(0 \cdot 98)\end{array}$ & $\begin{array}{c}79 \cdot 8(1 \cdot 3) \\
290 \cdot 4(1 \cdot 1) \\
2 \cdot 53(1 \cdot 1)\end{array}$ & $\begin{array}{l}\text { NS } \\
\text { NS } \\
\text { NS }\end{array}$ \\
\hline Exhaled nitric oxide (ppb) & $12 \cdot 3(1 \cdot 7)$ & $16 \cdot 2(3 \cdot 3)$ & NS \\
\hline $\begin{array}{l}\text { Mean capsaicin concentration } \\
\text { causing }>2 \text { coughs }(\mu M)\end{array}$ & $13 \cdot 5(2 \cdot 0)$ & $6 \cdot 5(2 \cdot 1)$ & NS \\
\hline $\begin{array}{l}\text { Median cough counts with } \\
\text { low } \mathrm{Cl}^{-} \text {inhalation: } \\
0 \mathrm{mM} \\
37.5 \mathrm{mM} \\
75 \mathrm{mM} \\
150 \mathrm{mM}\end{array}$ & $\begin{array}{l}2 \cdot 5 \\
5 \cdot 5 \\
0 \\
0\end{array}$ & $\begin{array}{l}1 \\
5 \cdot 5 \\
0 \\
0\end{array}$ & $\begin{array}{l}\text { NS } \\
\text { NS } \\
\text { NS } \\
\text { NS }\end{array}$ \\
\hline
\end{tabular}

Values are mean (SEM) except for cough counts with low-concentration chloride inhalation. $\mathrm{CI}^{-}$, chloride; $\mathrm{FEV}_{1}$, forced expiratory volume in 1 second; FVC, forced vital capacity; PC20 provocation concentration which caused a $20 \%$ drop in $\mathrm{FEV}_{1}$. two readings measured at end-exhalation were taken. The coefficient of variation (a means of assessing the reproducibility of exhaled nitric oxide concentration) in our laboratory is $7 \cdot 4 \%$, with most healthy non-smoking individuals having a recording of $<20 \mathrm{ppb}$.

\section{STATISTICAL ANALYSIS}

Paired and unpaired Student's $t$ tests were used where appropriate to assess the significance of results. Logarithmic transformation of PC20 and of capsaicin concentration causing two or more coughs were used in the analysis of results. For the cough response to low-concentration chloride solutions, median cough counts were used and the significance of results was assessed by the Mann-Whitney $\mathrm{U}$ test.

\section{Results}

Patients with chronic heart failure had New York Heart Association class II to IV symptoms (table 1). They had lower peak oxygen consumption than the controls $(16.9(1.3) v$ $26.5(2.3) \mathrm{ml} / \mathrm{kg} / \mathrm{min}, \mathrm{P}<0.01)$ consistent with moderately to severely impaired exercise tolerance. The results of the PC20 for methacholine and sodium metabisulphite are summarised in table 2 with the results of individual heart failure patients and controls given in tables 3 and 4 respectively. The geometric mean PC20 for methacholine was $67.6(1 \cdot 3)$ $\mathrm{mg} / \mathrm{ml}$ in chronic heart failure and $79.8(1.3)$ $\mathrm{mg} / \mathrm{ml}$ in controls $(\mathrm{P}=0.71)$ and for sodium metabisulphite, $276.7(1 \cdot 2)$ and $290.4(1 \cdot 1)$ $\mathrm{mg} / \mathrm{ml}(\mathrm{P}=0.79)$ respectively. As noted in tables 3 and 4 , the fall in $\mathrm{FEV}_{1}$ remained $<20 \%$ in many subjects at the maximum methacholine and sodium metabisulphite concentrations used in this study $(64 \mathrm{mg} / \mathrm{ml}$ and $160 \mathrm{mg} / \mathrm{ml}$ respectively). To ensure that the mean PC20 obtained for chronic heart failure patients and controls by arbitrarily assuming the PC20 in this subset of subjects to be the next doubling concentration of $128 \mathrm{mg} / \mathrm{ml}$ and $320 \mathrm{mg} / \mathrm{ml}$ for methacholine and sodium metabisulphite respectively did not lead to a misinterpretation of the results, we also analysed the percentage decrease in $\mathrm{FEV}_{1}$ from baseline at the provocation concentration of $32 \mathrm{mg} / \mathrm{ml}$ for methacholine and at 160 $\mathrm{mg} / \mathrm{ml}$ for sodium metabisulphite. A methacholine concentration of $32 \mathrm{mg} / \mathrm{ml}$ was used 
Table 3 Patients with pulmonary function, bronchial responsiveness, and exhaled nitric oxide concentration in individual chronic heart failure (CHF)

\begin{tabular}{|c|c|c|c|c|c|c|c|c|}
\hline $\begin{array}{l}\text { CHF } \\
\text { patient }\end{array}$ & $\begin{array}{l}F E V_{1}(\% \\
\text { predicted) }\end{array}$ & $\begin{array}{l}F V C(\% \\
\text { predicted) }\end{array}$ & $\begin{array}{l}P C 20 \mathrm{MCh} \\
(\mathrm{mg} / \mathrm{ml})\end{array}$ & $\begin{array}{l}P C 20 \mathrm{MBS} \\
(\mathrm{mg} / \mathrm{ml})\end{array}$ & $\begin{array}{l}\text { Pre-exercise } \\
F E V_{1} \text { (l) }\end{array}$ & $\begin{array}{l}\text { Post-exercise } \\
F E V_{1} \text { (l) }\end{array}$ & $\begin{array}{l}\text { \% change } \\
\text { in } F E V_{1}\end{array}$ & $\begin{array}{l}\text { Nitric oxide } \\
(p p b)\end{array}$ \\
\hline $\begin{array}{r}1 \\
2 \\
3 \\
4 \\
5 \\
6 \\
7 \\
8 \\
9 \\
10\end{array}$ & $\begin{array}{c}93 \cdot 9 \\
111 \\
102 \\
76 \cdot 3 \\
111 \\
90 \\
121 \\
82 \\
100 \\
96.5\end{array}$ & $\begin{array}{c}103 \\
124 \\
99 \\
74 \cdot 6 \\
111 \\
92 \\
125 \\
83 \cdot 3 \\
121 \\
104\end{array}$ & $\begin{aligned}> & 64 \\
& 55 \cdot 71 \\
& 8 \cdot 00 \\
> & 64 \\
> & 64 \\
> & 64 \\
> & 64 \\
> & 64 \\
& 23.42 \\
& 43.63\end{aligned}$ & 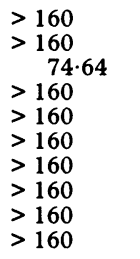 & $\begin{array}{l}1 \cdot 63 \\
2 \cdot 66 \\
2 \cdot 90 \\
2 \cdot 39 \\
3 \cdot 16 \\
3 \cdot 87 \\
1.92 \\
1 \cdot 62 \\
1 \cdot 72 \\
2 \cdot 35\end{array}$ & $\begin{array}{l}1.63 \\
2 \cdot 72 \\
3.08 \\
2 \cdot 44 \\
3.15 \\
3.97 \\
1.94 \\
1.53 \\
1.76 \\
2 \cdot 44\end{array}$ & 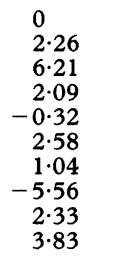 & $\begin{array}{l}13 \\
10 \\
20 \cdot 5 \\
19 \cdot 5 \\
8 \\
8 \\
\text { Not done } \\
11 \\
15 \\
5 \cdot 5\end{array}$ \\
\hline
\end{tabular}

$\mathrm{FEV}_{1}$, forced expiratory volume in 1 second; FVC, forced vital capacity; PC20, provocation concentration which caused a $20 \%$ drop in $\mathrm{FEV}_{1} ; \mathrm{MCh}$, methacholine; MBS, sodium metabisulphite.

Table 4 Pulmonary function, bronchial responsiveness, and nitric oxide concentration of individual controls. The age, sex and radiographic cardiothoracic ratio are also given

\begin{tabular}{|c|c|c|c|c|c|c|c|c|c|c|}
\hline Controls* & $\begin{array}{l}\text { Age (y)/ } \\
\text { sex }\end{array}$ & $\begin{array}{l}\text { CXR } \\
C T R\end{array}$ & $\begin{array}{l}F E V_{I}(\% \\
\text { predicted) }\end{array}$ & $\begin{array}{l}F V C(\% \\
\text { predicted) }\end{array}$ & $\begin{array}{l}P C 20 \mathrm{MCh} \\
(\mathrm{mg} / \mathrm{ml})\end{array}$ & $\begin{array}{l}P C 20 \mathrm{MBS} \\
(\mathrm{mg} / \mathrm{ml})\end{array}$ & $\begin{array}{l}\text { Pre-exercise } \\
F E V_{l}(l)\end{array}$ & $\begin{array}{l}\text { Post-exercise } \\
F E V_{1} \text { (l) }\end{array}$ & $\begin{array}{l}\% \text { change } \\
\text { in FEV }\end{array}$ & $\begin{array}{l}\text { Nitric oxide } \\
(p p b)\end{array}$ \\
\hline $\begin{array}{l}1 \\
2 \\
3 \\
4 \\
5 \\
6 \\
7 \\
8\end{array}$ & $\begin{array}{l}42 M \\
65 M \\
46 M \\
55 F \\
63 M \\
52 M \\
58 F \\
53 F\end{array}$ & $\begin{array}{l}0.45 \\
0.43 \\
0.48 \\
0.48 \\
0.49 \\
0.45 \\
0.45 \\
0.48\end{array}$ & $\begin{array}{l}102 \\
114 \\
109 \\
122 \\
114 \\
102 \\
113 \\
104\end{array}$ & $\begin{array}{l}101 \\
127 \\
112 \\
121 \\
107 \\
110 \\
114 \\
109\end{array}$ & $\begin{aligned}> & 64 \\
> & 64 \\
& 17 \cdot 08 \\
> & 64 \\
& 22 \cdot 01 \\
> & 64 \\
> & 64 \\
> & 64\end{aligned}$ & $\begin{aligned}> & 160 \\
> & 160 \\
> & 160 \\
> & 160 \\
& 148 \cdot 33 \\
> & 160 \\
> & 160 \\
> & 160\end{aligned}$ & $\begin{array}{l}2 \cdot 82 \\
2 \cdot 83 \\
3 \cdot 17 \\
2 \cdot 56 \\
2 \cdot 35 \\
2 \cdot 44 \\
2 \cdot 23 \\
3 \cdot 49\end{array}$ & $\begin{array}{l}2 \cdot 82 \\
2 \cdot 91 \\
3 \cdot 31 \\
2 \cdot 62 \\
2 \cdot 44 \\
2 \cdot 64 \\
2 \cdot 20 \\
3 \cdot 49\end{array}$ & $\begin{array}{l}0 \\
2 \cdot 83 \\
4 \cdot 42 \\
2 \cdot 34 \\
3 \cdot 82 \\
8 \cdot 20 \\
-1.35 \\
0\end{array}$ & $\begin{array}{l}33 \\
27 \\
13 \cdot 5 \\
6 \cdot 5 \\
8 \cdot 5 \\
18 \\
13 \cdot 5 \\
8.5\end{array}$ \\
\hline
\end{tabular}

CXR CTR, radiographic cardiothoracic ratio; $\mathrm{FEV}_{1}$, forced expiratory volume in 1 second; FVC, forced vital capacity; PC20, provocation concentration which caused a $20 \%$ drop in $\mathrm{FEV}_{1} ; \mathrm{MCh}$, methacholine; $\mathrm{MBS}$, sodium metabisulphite.

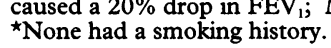

because nine of the 10 chronic heart failure patients completed the bronchial provocation test at this concentration compared with only eight at $64 \mathrm{mg} / \mathrm{ml}$. The decrease in $\mathrm{FEV}_{1}$ was $13.7 \% v 13.4 \%(\mathrm{P}=0.97)$ for methacholine and $5.5 \%$ v $9.9 \%(P=0.2)$ for sodium metabisulphite in patients with chronic heart failure and in controls respectively, which confirmed that there was no significant difference between the two groups of subjects.

As shown in table 2, the change in $\mathrm{FEV}_{1}$ after maximal cardiopulmonary exercise testing was $+1.44 \%$ in chronic heart failure patients and $+2.53 \%$ in controls $(P=0.47)$, indicating an absence of exercise-induced bronchospasm in both groups. Exhaled nitric oxide concentration was not increased in the patients with chronic heart failure (12.3 (1.7) $v 16 \cdot 2(3 \cdot 3) \mathrm{ppb}, \mathrm{P}=0.32)$.

The results of the cough response to lowconcentration chloride solutions and capsaicin are also given in table 2 . The median cough counts in chronic heart failure patients were not different from controls for the various lowconcentration chloride solutions. The capsaicin concentration causing two or more coughs in chronic heart failure patients was also not significantly different from controls.

\section{Discussion}

We were unable to detect any significant airway hyper-responsiveness in patients with stable chronic heart failure in our study. Compared with previous studies, we were more selective in the recruitment criteria in excluding patients with a history of acute pulmonary oedema within six months and of smoking within five years to avoid possible confounding factors. We also assessed airway responsiveness to a wider range of stimuli.
Airway responsiveness is affected not only by bronchial smooth muscle tone but also by the bronchial vascular tone ${ }^{2}$ and the activity of autonomic fibres innervating the airways. ${ }^{13}$ In view of this, two different pharmacological agents, methacholine and sodium metabisulphite, with different modes of action were chosen to assess airway responsiveness. Methacholine, a commonly used agent and an analogue of acetylcholine, acts directly on airway smooth muscle and is a dilator of bronchial vessels. ${ }^{14}$ On the other hand, sodium metabisulphite is a putative stimulant of airway sensory nerves. The observation that patients with chronic heart failure in our study did not show an excessive narrowing of airways with either agent suggests that neither airway smooth muscle hyperresponsive nor its neural activity was upregulated.

Similarly, we were unable to demonstrate airway hyper-reactivity in response to exercise. All the patients were subjected to a maximal treadmill exercise test with a respiratory exchange ratio of $>1 \cdot 1$ at peak exercise and all breathed through the mouth which should have accentuated exercise-induced bronchospasm had this been present. ${ }^{15}$

Our findings that airways are not hyperresponsive in stable chronic heart failure parallel those of Eichacker et al. ${ }^{6}$ Several subsequent studies have suggested otherwise. ${ }^{2-4}$ There are several possible reasons for the discrepancy. In general, the size of the previous studies in this area was small. Patients with a recent history of acute decompensation and pulmonary congestion were also included in some studies ${ }^{2}{ }^{3}$ whereas in another, diuretics were stopped before the tests, ${ }^{4}$ perhaps inducing airway oedema. Although tests were performed when patients had clinically recovered from the acute event, airways may remain 
hyper-responsive as shown by Pison et al. ${ }^{3}$ It may be that a reduction in airway hyperresponsiveness lags behind the clinical recovery of pulmonary congestion. Studies on airway function in patients with acute heart failure generally confirm an obstructive airway pattern. ${ }^{16-18}$ This is probably related to peribronchial oedema and vascular congestion. ${ }^{19}$ Indeed, Light and George in a study with a mean follow up of 310 days showed that despite some initial improvement this obstructive pattern persisted for a long time even in non-smokers. ${ }^{16}$ How then do acute decompensation and the resultant obstructive airways explain airway hyper-responsiveness? There are several possibilities. It is well known that there is an inverse relation between airway calibre, for which obstructive lung function is an index, and bronchial hyper-responsiveness..$^{20}$ The resistance to flow in a tube is inversely proportional to the radius of the tube to the fourth power and thus the effect of spasm on airway narrowing in an already narrowed airway is greatly amplified, even if the tone of smooth muscle contraction is no more than normal. ${ }^{22}$ Secondly, narrowed airways facilitate central deposition of aerosol, thus enhancing airway constriction. ${ }^{23}$ The additional vasodilatory effects of methacholine on bronchial vessels may also aggravate any peribronchial vascular congestion and oedema already present.

Another possible confounding factor is smoking. Smoking leads to different degrees of airway obstruction ${ }^{24}$ and as discussed above, an altered baseline lung function will affect bronchial responsiveness on the basis of simple geometric considerations. In addition, smoking may have direct effects on airway responsiveness. ${ }^{202125}$

It has been suggested that local inflammation may explain the increased airway responsiveness in some patients. ${ }^{3}$ We indirectly assessed this by measuring the exhaled nitric oxide concentration in our patients. Endogenous nitric oxide is synthesised from the amino acid L-arginine by the action of nitric oxide synthase, which has three main isoforms. ${ }^{26}$ Constitutive forms of the enzyme are found in endothelial cells which produce nitric oxide (endothelium-derived relaxing factor) responsible for endothelium-dependent vasodilatation, and in neurons, where nitric oxide acts as a neurotransmitter. The other form of the enzyme is the enzyme induced by the action of endotoxin and proinflammatory cytokines in various cell types including leucocytes. Exhaled nitric oxide concentration is increased as a result of inducible enzyme in inflammatory airway diseases such as asthma and bronchiectasis. ${ }^{910}$ The finding that exhaled nitric oxide concentration is not increased suggests that local inflammation is not present in patients with stable chronic heart failure. This finding is also compatible with the other results in our study.

The cough response to low-concentration chloride solutions and to capsaicin in patients with chronic heart failure was not significantly different from controls. Afferent fibres of the cough reflex arise in the pulmonary stretch $(J)$ receptors via $c$ fibres $^{27}$; the receptors in the upper airways ${ }^{28}{ }^{29}$; and the $c$ fibre endings in the mucosa of the larynx, trachea, and bronchi. ${ }^{3031}$ The $c$ fibres are stimulated by capsaicin ${ }^{32}$ and if airway hyper-responsiveness is mediated by the stimulation of $\mathrm{J}$ receptors and $\mathrm{c}$ fibres by increased pulmonary venous pressures this agent would be expected to enhance the cough reflex. Our finding that the cough response was not different from that in the controls is compatible with the general finding that the airways were not hyper-responsive in our study.

In summary, we were not able to demonstrate any significant airway hyper-responsiveness, either to pharmacological agents or to exercise, in non-smoking patients with stable non-oedematous chronic heart failure receiving, and tolerant to, angiotensin-converting enzyme inhibitors. Exhaled nitric oxide concentration and the cough response were also not enhanced, suggesting that there was no local inflammation or upregulated neural mechanisms. It is therefore unlikely that airway hyper-responsiveness contributes significantly to the exertional dyspnoea seen in chronic heart failure patients in a stable condition. However, our findings do not exclude the presence of airway hyper-responsiveness in patients with acute pulmonary oedema or during the recovery period.

\section{LIMITATIONS OF THE STUDY}

Because of the selective recruitment criteria, the number of patients in this study was small and may have limited the study. Another potential limitation is that all the patients with chronic heart failure were receiving angiotensin-enzyme inhibitors which may have altered airway responsiveness and the cough reflex. We chose a control group of asymptomatic hypertensive patients also taking angiotensin-converting enzyme inhibitors to circumvent this possible confounding factor. In any case, no subjects had a history of intolerance of the medication or of developing a cough during treatment. Had angiotensinconverting enzyme inhibitors affected the results, an abnormal cough response ${ }^{33}$ and an increased airway responsiveness should have been present but neither was seen. In an earlier study patients who coughed during treatment with angiotensin-converting enzyme inhibitors also had bronchial hyper-reactivity when they were not receiving the treatment. ${ }^{34}$ It is thus possible that the patients in our study had already been "pre-selected" by virtue of their tolerance to angiotensin converting enzyme inhibitors-that is, patients intolerant of this class of drug may indeed have latent bronchial hyper-responsiveness despite the absence of a history of asthma or asthmatic symptoms, such variation has been recognised in other studies. ${ }^{35-39}$ The development of airway hyperresponsiveness may thus be complex and multifactorial in origin, depending on genetic characteristics, pathophysiological mechanisms, and environmental factors (such as smoking, pollution and concomitant respiratory tract infection). 
TPC is supported by a junior research fellowship from the British Heart Foundation. AJSC is supported by the Viscoun Royston Trust and British Heart Foundation.

1 Britton J, Tattersfield AE. Does measurement of bronchial hyperreactivity help in the clinical diagnosis of asthma? Eur ₹ Respir Dis 1986;68:233-8.

2 Cabanes LR, Weber SN, Matran R, Regnard J, Richard MO, Degeorges ME, et al. Bronchial hyperresponsiveness to methacholine in patients with impaired left
ventricular function. $N$ Engl $f$ Med 1989;320: ventricular

3 Pison C, Malo J-L, Rouleau J, Chalaoui J, Ghezzo H, Malo J. Bronchial hyperresponsiveness to inhaled methacholine in subjects with chronic left heart failure at a time of execerbation and after increasing diuretic therapy. of execerbation and a

4 Sasaki F, Ishizaki T, Mifune J, Fujimura M, Nishioka S, Miyabo S. Bronchial hyperresponsiveness in patients with chronic congestive heart failure. Chest 1990;97: 534-8.

5 Brunee T, Graf K, Kastens B, Fleck E, Kunkel G. Bronchial hyperreactivity in patients with moderate pulmonary circulation overload. Chest 1993;103:1477-81.

6 Eichacker PQ, Seidelman MJ, Rothstein MS, Lejemtel T Methacholine bronchial reactivity testing in patients with
chronic congestive heart failure. Chest 1988;93:336-8.

chronic congestive heart failure. Chest 1988;93:336-8.
Seibert AF, Allison RC, Bryars CH, Kirkpatrick MB Normal airway responsiveness to methacholine in cardiac asthma. Am Rev Respir Dis 1989;140:1805-6.

8 Chung KF, Keyes SJ, Morgan, Jones PW, Snashall PD. Mechanisms of airway narrowing in acute pulmonary oedema: influence of the vagus and lung volume. Clin Sci 1983;65:289-96.

9 Kharitonov SA, Yates D, Robbins RA, Logan-Sinclair R, Shinebourne EA, Barnes PJ. Increased nitric oxide in exhaled air of asthmatic patients. Lancet 1994;343:133-5.

10 Kharitonov SA, Wells AU, O'Connor BJ, Cole PJ, Hansell DM, Logan-Sinclair RB, et al. Elevated levels of exhaled nitric oxide in bronchiectasis. Am $\mathcal{F}$ Respir Crit Care Med 1995;151:1889-93.

11 Davies N, Denison DM. The measurement of metabolic gas exchange and minute ventilation by mass spectrometry alone. Resp Physiol 1979;36:261-7.

12 Bruce RA, Blackman JR, Jones JW. Exercise testing in adult normal subjects and cardiac patients. Pediatrics 1963;32:742-55.

13 Barnes PJ. Neural control of human airways in health and disease. Am Rev Respir Dis 1986;134:1289-1314.

14 Laitinen LA, Laitinen MV, Widdicombe JG. Parasympathetic nervous control of tracheal vascular resistance in the dog. $f$ Physiol (Lond) 1987;385 $135-46$

15 Cherniack RM. Assessment of ventilatory function. In: Pulmonary function testing. 2nd ed. Philadelphia: WB Saunders, 1992:135-74.

16 Light RW, George RB. Serial pulmonary function in patients with acute heart failure. Arch Intern Med 1983 143:429-33

17 Petermann W, Barth J, Entzian P. Heart function and airway obstruction. Int $\mathcal{F}$ Cardiol 1987;17:207-9.

18 Chua TP, Coats AJS. The lungs in chronic heart failure. $E$ Heart f 1995;16:882-7.

19 Hogg JC, Agrawal JB, Gardiner AJS, Palmer WH, Macklem PT. Distribution of airway resistance with developing pulmonary edema in dogs. $\mathcal{F}$ Appl Physiol 1972;32:20-4.

20 Sparrow D, O'Connor GT, Colton T, Barry CL, Weiss
ST. The relationship of nonspecific bronchial responsiveness to the occurence of respiratory symptoms and decreased levels of pulmonary function in adults. $A m$ Rev Respir Dis 1984;130:198-203.

21 Paoletti P, Carrozzi L, Viegi G, Modena P, Ballerin L, Di Pede F, et al. Distribution of bronchial responsiveness in a general population: effect of sex, age, smoking, and level of pulmonary function. Am $\mathcal{F}$ Respir Crit Care Med 1995;

22 Moreno RH, Hogg JC, Pare PD. Mechanics of airway narrowing. Am Rev Respir Dis 1986;133:1171-80.

23 Dolovich MB, Shanchis J, Rossman C, Newhouse MT Aerosol penetrance: a sensitive index of peripheral airway obstruction. 7 Appl Physiol 1976;40:468-71.

24 Niewoehner DE, Kleinerman J, Rice B. Pathologic changes in the peripheral airways of young cigarette smokers. $N$ Engl F Med 1974;291:755-8.

25 Gerrard J, Cockroft D, Mink J, Cotton D, Poonawala R, Dosman J. Increased non-specific bronchial reactivity in cigarette smokers with normal lung function. $\mathrm{Am} R e v$ Respir Dis 1980;122:577-81.

26 Moncada S, Higgs A. The L-arginine-nitric oxide pathway. $N$ Engl f Med 1993;329:2002-12.

27 Hanacek J, Davies A, Widdicombe JG. Influence of lung stretch receptors on the cough reflex in rabbits. Respiration 1984;45:161-8.

28 Widdicombe JG. Receptors in trachea and bronchi of the cat. F Physiol (Lond) 1954;123:71-104.

29 Sant'Ambrogio G, Remmers JE, De Groot WJ, Callas CT, Mortola JP. Localisation of rapidly adapting receptors in the trachea and main stem bronchus of the dog. Respir Physiol 1978;33:359-66. 30 Coleridge JGG, Coleridge HM. Afferent vagal c-fibre
innervation of the lings and airways and its functional significance. Rev Physiol Biochem Pharmacol 1984;99: 101-10.

31 Sant'Ambrogio G. Afferent pathways for the cough reflex. Bull Eur Physiopathol Respir 1987;23(suppl 10):19S-24S.

32 Coleridge HM, Coleridge JGG, Luck JC. Pulmonary afferent fibres of small diameter stimulated by capsaicin and by hyperinflation of the lungs. I Physiol (Lond) 1965; 179:248-62.

33 Fuller RW, Choudry NZ. Increased cough reflex associated with angiotensin converting enzyme inhibitor cough. $\mathrm{Br}$ with angiotensin converting

34 Bucknall CE, Neilly JB, Carter R, Stevenson RD, Semple $\mathrm{PF}$. Bronchial hyperreactivity in patients who cough after receiving angiotensin converting enzyme inhibitors. $B$ Med f 1988;296:86-8.

35 Rijcken B, Schouten JP, Weiss ST, Speizer FE, van der Lende $R$. The relationship of nonspecific bronchial responsiveness to respiratory symptoms in a random population sample. Am Rev Respir Dis 1987;136:62-68.

36 Woolcock AJ, Peat JK, Salome CM, Yan K, Anderson SD, Schoeffel G, et al. Prevalence of bronchial hyperresponsiveness and asthma in a rural adult population. Thorax 1987;42:361-8.

37 Burney PGJ, Britton JR, Chinn S, Tattersfield AE, Papacosta AO, Kelson MC, et al. Descriptive epidemiology of bronchial reactivity in an adult population: results from a community study. Thorax 1987;42:38-44.

38 Cerveri I, Bruschi C, Zola MC, Zanon P, Maccarini M, Grassi $\mathrm{M}$, et al. Distribution of bronchial non-specific reactivity in the general population. Chest 1988;93: 26-30.

39 Bakke PS, Baste V, Gulsvik A. Bronchial responsiveness in a Norwegian community. Am Rev Respir Dis 1991;143: 317-22. 